\title{
Kısıtlı Sulama ve Kükürt Dozu Uygulamalarının Soya Fasulyesinde Bitki Gelişimi ve Klorofil (SPAD) İçeriğine Etkisi
}

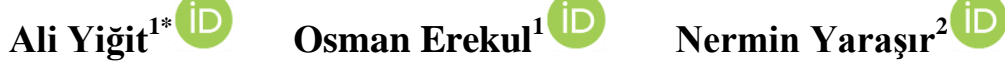 \\ ${ }^{1}$ Aydın Adnan Menderes Üniversitesi Ziraat Fakültesi Tarla Bitkileri Bölümü, 09100 Aydın, \\ ${ }^{2}$ Aydın Adnan Menderes Üniversitesi Fen Bilimleri Enstitüsü, 09100 Aydın \\ *Sorumlu yazar : ali.yigit@adu.edu.tr
}

Geliş Tarihi: 12.02.2021

Kabul Tarihi: 11.03.2021

\section{$\ddot{O} \mathbf{z}$}

Bu çalışma farklı sulama miktarı ve kükürt dozlarının soya fasulyesinde yaprak klorofil içeriği, verim ve verim öğeleri üzerine etkilerini belirlemek amaciyla yürütülmüştür. $\mathrm{Bu}$ amaçla yarı-kontrollü sera koşullarında saksı çalışması 2017 ve 2018 yıllarında üç farklı soya fasulyesi çeşidi (Cinsoy, Arısoy ve Umut2002), gravimetrik yöntem ile belirlenen tarla kapasitesine göre hesaplanan ve ekimden 30 gün sonra uygulanan tam sulama (\%75 ve \%100 tarla kapasitesi) ve kısıtlı sulama (\%25 ve \%50 tarla kapasitesi) koşulları ile iki farklı kükürt dozu ( 0 ve $5 \mathrm{~kg} / \mathrm{da}$ ) kullanılarak yürütülmüştür. Çalışmada bitki boyu, ilk bakla yüksekliği, bitkide bakla sayısı, bin tane ağırlığı, tek bitki verimi, bakla bağlama $(\mathrm{BBCH} 75)$ ve tane dolum (BBCH 85) dönemlerinde SPAD klorofil ölçümleri yapılmıştır.

Sonuç olarak, sulama koşullarının incelenen tüm parametreler düzeyinde istatistiksel olarak önemli düzeyde $(p<0.01)$ etkisi bulunmuştur. En yüksek bitki verimi (18.6 g/bitki) 2018 y1lında \%100 tarla kapasitesinde ve $5 \mathrm{~kg} /$ da kükürt dozunda Cinsoy çeşidi ile elde edilirken, en düşük verim (3.1 g/bitki) 2017 yılında \%25 tarla kapasitesinde ve $5 \mathrm{~kg} /$ da kükürt dozunda Umut-2002 çeşidinde bulunmuştur. SPAD klorofil içeriği ise sulama miktarlarına bağlı olarak önemli düzeyde artarken, bakla bağlama ve tane dolum dönemlerinde ise çeşitlere bağlı olarak değiştiği tespit edilmiştir.

Anahtar Kelimeler: soya fasulyesi, kısıtlı sulama, kükürt, verim, SPAD

\section{The Effects of Deficit Irrigation and Sulphur Fertilization on Soybean Growth and Chlorophyll (SPAD) Content}

\section{Abstract}

In our study, we evaluated soybean leaf chlorophyll, yield and yield attributes change under different water amounts and sulphur fertilizer conditions. For this purpose; a pot experiment conducted in semi-controlled greenhouse conditions by using three soybean varieties (Cinsoy, Arısoy and Umut-2002), four soil moisture treatments calculated based on gravimetric method imposed from 30 days after sowing: well-watered (75\% and $100 \%$ field capacity) and deficit irrigation (50\% and 25\% field capacity) and two different sulphur doze ( 0 and 5 $\mathrm{kg} / \mathrm{da})$. Plant height, the lowest pod height, filled pods plant ${ }^{-1}$, thousand-grain weight, grain yield plant ${ }^{-1}$ and SPAD chlorophyll measurements in pod development $(\mathrm{BBCH} 75)$ and grain filling $(\mathrm{BBCH} 85)$ periods were evaluated.

As a result of the study, analysis of variance showed that all parameters were significantly affected by irrigation regimes $(p<0.01)$. While the highest average seed yield $(18.6 \mathrm{~g} / \mathrm{plant})$ was observed at $100 \%$ field capacity and $5 \mathrm{~kg} / \mathrm{da}$ sulphur dose with Cinsoy variety in 2018, the lowest yield (3.1 g/plant) was found at $25 \%$ field capacity and $5 \mathrm{~kg} / \mathrm{da}$ sulphur dose with Umut-2002 variety in 2017 growing period. SPAD chlorophyll content directly increased with water amount of soil and changed by variety both pod development and grain filling periods.

Keywords: soybean, deficit irrigation, sulphur, yield, SPAD

\section{Giriş}

Dünya'da hızla değişen ekolojik koşulların kısa sürede tanımlanması ve çözüm oluşturulması ile buna bağlı artan nüfusun yeterli ve sağlıklı beslenmesini sağlamak ancak bu değişime uygun tarımsal üretim sistemlerin geliştirilmesi ile mümkün görülmektedir. Soya fasulyesi çok değerli besin maddeleri içermesi nedeniyle insan beslenmesinde, hayvan beslenmesinde ve sanayi ham maddesi olarak değerlendirildiği bilinmektedir. Tarla Bitkileri içerisinde Dünya'da çok önemli bir yere sahip 
olan soya bitkisi ülkemizde ancak 35,295 ha alanda ekilmektedir, üretimi ise yaklaşık 150,000 ton olup verimi $424 \mathrm{~kg} /$ da'dır (FAOSTAT, 2019). Böylece ülkemizde ekim alanına bağlı olarak üretimi dünya geneline göre çok az bir seviyede bulunmaktadır ve buna bağlı olarak soya ithalatı son yıllarda 2.7 milyon ton kadar olmaktadır. Bu durum ağırlıklı olarak yem sanayinde değerlendirmek üzere soya ihtiyacının \% 95 (yeterlilik \% 4.8) düzeyinde dışarıdan ithal yoluyla karşılandığı anlamına gelmektedir (TÜiK, 2019).

Son yıllarda etkileri daha da belirgin hale gelen bitki sağlığı ve gida güvenliği konularını büyük ölçüde etkileyen iklim değiş̧ikliği tarımsal üretim için büyük bir tehdit oluşturmaktadır. 19812010 yılları arasında meydana gelen iklim değişiklikleri dikkate alınarak yapılan projeksiyon çalışmalarında Dünya çapında mısır, buğday ve soya fasulyesi bitkilerinin verimleri sırasıyla \% 4.1, 1.8 ve 4.5 düzeyinde azalacağı ve sera gazı artışı ile C3 bitkilerinin (soya, buğday, çeltik, yulaf gibi) C4 bitkilerine oranla yüksek sicaklıklara daha da hassas hale geleceği belirtilmiştir (Mbow ve ark., 2019).

Tarımsal üretimde baklagillerin kullanılmaya başlanması iklim değişikliğine karşı önemli bir rol oluşturabilir. Soya fasulyesinde topraktaki kuraklık ve kısıtlı sulama koşullarında azot fiksasyonu azalmakta dolayısıyla düşük protein üretimi ve yetersiz tane gelişim düzeyi nedeniyle verim ve kalitede önemli düşüşler gözlemlenmektedir (Sinclair ve ark., 2007). Kumlu topraklarda vejetatif gelişme döneminde kuraklık stresine maruz bırakılan ve azotlu gübre uygulanmayan bitkilerde stres dönemi boyunca yaprak ve baklalarda azot birikiminin \% 30-40 düzeyinde azaldığ belirlenerek kuraklığın azot fiksasyonu üzerine önemli düzeyde negatif etkisinin olduğu bildirilmiştir (Streeter, 2003).

Akdeniz iklimi koşullarında son yıllarda yarı kurak bölgelerde daha uzun süren sıcaklık periyotları görülmektedir. Bu nedenle bu bölgede iklim değişikliği daha da etkili bir şekilde hissedilmektedir. Yarı kurak bölgelerde uzun sıcaklık periyotlarının ve aşırı sıcak koşulların görülmesi bitkisel üretimde su kıtlığını açığa çıkartmaktadır (Koca ve ark., 2015). Yazlık olarak yetiştirilen ve yağışın yeterli olmadığı durumlarda yapılan ek sulama soya fasulyesinde verimi önemli düzeyde arttırdığı ancak kaynakların yetersiz kaldığ 1 kurak, yarı kurak ve yarı nemli bölgelerde kısıtlı sulama uygulamalarının ise zorunluluk haline geldiği araştırıcılar tarafından belirtilmektedir (Sincik ve ark., 2008). Yüksek sıcaklık ve kuraklık stresinin de bitkinin büyüme ve gelişimi üzerine ve dolayısıyla tane verimini önemli düzeyde düşürdüğünü ve özellikle verim öğelerinden bitkide bakla sayısında büyük azalmaların yaşandığı belirtilmiştir (Hu ve Wiatrale, 2012). Kuraklık koşullarında su faktörünün verimi belirleyen en önemli etken olduğu özellikle generatif dönemler olan çiçeklenme ve bakla olum dönemlerindeki su kıtlığı çiçeklenme oranının ve dolayısıyla bitkide bakla sayısı azalmasına neden olarak bitki verimini etkileyen en önemli etkenler olduğu belirtilmiştir (He ve ark., 2017). SPAD klorofil ölçümü kolay kullanımı ve hızlı ölçümü sayesinde yaprak klorofil içeriğinin belirlenmesinde yaprak yeşilliğinin ölçülmesi ile kullanılmaktadır. Özellikle su stresi koşullarında bitkideki azot durumunun belirlenmesi, yapraktaki azot varlığı ile yaprak klorofil durumu ile doğrudan ilişkili olması nedeniyle bitkideki klorofil ve fotosentez durumu hakkında önemli düzeyde bilgi sağlamaktadır (Ahmed ve ark., 2010).

Alkali topraklarda yüksek $\mathrm{pH}$ değeri besin elementlerinin bitkilere yarayışlı hale gelmesinde önemli bir engel oluşturmaktadır. Son yıllarda özellikle Akdeniz havzasında orta alkali topraklarda; kükürt eksikliğinin görüldügü ve yapılan uygulamaların bitki verimi ile azot fiksasyonunu artırmış ve optimum protein ve tohum verimi elde etmek için tavsiye edilir olduğu bildirilmiştir (Cazzato ve ark., 2012; Ercoli ve ark., 2012; Divito ve ark., 2013). Kükürt; metiyonin (\%21 S) ve sistin (\% 27 S) yapısında, protein ve klorofil sentezinde ve tohumlardaki yağ içeriğindeki rolü ile bilinir (Jamal ve ark., 2006). Genellikle kükürtlü gübre uygulaması ile nodül sayısı, bitki boyu, bakla uzunluğu, bitkide bakla sayısı, protein, yağ ve amino asit içeriğinde artış sağlanmıştır (Jaga, 2013). Kükürt eksikliği sadece bitkilerde azot metabolizmasını etkilemekle kalmamakta ayrıca baklagillerde simbiyotik azot fiksasyonu üzerine de nitrogenaz enzimi ve ferrodoksin yapısında bulunmasından dolayı önemli etkisi bulunmaktadır (Krusell ve ark., 2005).

Bütün bu bilgiler 1şığında yapılan çalışmada gelecek yıllarda yazlık üretimde etkileri daha da hissedilecek olan iklim değişikliğine karşı soya fasulyesinde kontrollü koşullar altında kısıtlı sulama uygulamaları ve kükürtlü gübreleme ile etkin su kullanımının ve verime yönelik değişimlerin bitki bazında ortaya konulması ve fizyolojik değişimlerin incelenmesi amaçlanmıştır. 


\section{Materyal ve Yöntem}

$\mathrm{Bu}$ araştırma soya fasulyesinde kısıtlı sulama ve kükürtlü gübrelemenin verim ve fizyolojik parametreler üzerine etkisini belirlemek amacıyla 2017 ve 2018 yıllarında Aydın Adnan Menderes Üniversitesi Ziraat Fakültesi Tarla Bitkileri Bölümü deneme seralarında yürütülmüştür. Kısıtlı sulama uygulamalarının etkisini daha belirgin olarak belirlemek ve bitkideki değişimini incelemek amacıyla çalışma, yarı kontrollü sera koşullarında yapılmıştır. Bu amaçla bitki materyali olarak Akdeniz iklimine uygun orta erkenci soya fasulyesi çeşitleri olan; Arısoy, Cinsoy ve Umut-2002 çeşitleri kullanılmıştır.

Saksı denemesinde araziden temin edilen toprak elekten geçirildikten sonra soya bitkilerinin rahat gelişebilmesi için $73 \mathrm{~cm}$ uzunluğunda, $31 \mathrm{~cm}$ eninde ve $30 \mathrm{~cm}$ derinliğinde toplam $67.890 \mathrm{~cm}^{3}$ saksılar kullanılmıştır. Her bir saksı için toplam $40 \mathrm{~kg}$ toprak kullanılarak \% 2.5 oranında perlit kullanılmıştır.

Çizelge 1. Denemede kullanılan toprağın analiz sonuçları $(0-20 \mathrm{~cm})$

\begin{tabular}{|c|c|c|c|c|c|c|c|c|}
\hline $\begin{array}{c}\mathrm{P} \\
\mathrm{ppm}\end{array}$ & $\begin{array}{c}\mathrm{K} \\
\mathrm{ppm}\end{array}$ & $\begin{array}{c}\mathrm{Ca} \\
\mathrm{ppm}\end{array}$ & $\begin{array}{l}\mathrm{Mg} \\
\mathrm{ppm}\end{array}$ & $\begin{array}{c}\mathrm{S} \\
\mathrm{mg} / \mathrm{kg}\end{array}$ & $\begin{array}{c}\mathrm{Na} \\
\mathrm{ppm}\end{array}$ & $\begin{array}{c}\mathrm{pH} \\
\text { Hafif Alkali }\end{array}$ & $\begin{array}{c}\text { Toplam Tuz } \\
\%\end{array}$ & $\begin{array}{c}\text { Organik Madde } \\
\%\end{array}$ \\
\hline 10.7 & 305 & 1745 & 475 & 7.8 & 95 & 8.3 & 0.032 & 1.7 \\
\hline
\end{tabular}

Toprağın kumlu-tınlı bünyeye sahip olduğu ve reaksiyonu hafif alkali karakterli olduğu, tuzsuz ancak organik madde miktarının düşük olduğu anlaşılmaktadır. Toprakta bulunan besin elementlerinin miktarına bakıldığında ise genel olarak kükürt miktarının düşük, fosfor, potasyum, kalsiyum ve sodyum miktarlarının yeterli, magnezyum miktarının ise yüksek olduğu görülmektedir (Çizelge 1).

Araştırmada kısıtlı ve tam sulama dozları toprağın su tutma kapasitesinin gravimetrik yöntem ile belirlenmesi ile tespit edilmiştir. Tarla kapasitesinin belirlenmesinde $4 \times 6 \mathrm{~cm}=100 \mathrm{~cm}^{3}$ 'lük silindirler kullanılarak bozulmuş toprak örnekleri ile doldurulan silindirlerin 3 saat su ile doyurulması ve 2 saat drene edilmesi sonucunda 24 saat $105^{\circ} \mathrm{C}$ etüvde kurutulması sonucu;

"'Toprak su tutma kapasitesi= [(yaş toprak ağırlığı-kuru toprak ağırlığı/kuru toprak ağırlığı)x100]", formülü ile hesaplanmıştır (Canavar ve ark., 2018).

Tarla su tutma kapasitesinin \% 23.8 olduğu belirlenerek Tarla kapasitesinin \%25 (TK $\% 25)$, $\% 50\left(\mathrm{TK}_{\% 50}\right), \% 75\left(\mathrm{TK}_{\% 75}\right)$ ve \%100 $\left(\mathrm{TK}_{\% 100}\right)$ 'ü olmak üzere su verilerek sulama konular1 belirlenmiştir. Toprağın su tutma kapasitesi belirlendikten ve ekimden 30 gün sonra saksıların her birinin toplam ağırlıkları dikkate alınarak her bir sulama dozu için gerekli su miktarları belirlenmiştir. Saksılar hava sıcaklığına bağlı olarak en geç 1-2 günde bir ağırlıkları terazi kontrol edilerek azalan su miktarları her bir sulama dozu dikkate alınarak ilave edilmiştir ve böylece istenilen nem miktarlarında kontrollü koşullarda tutulmuştur (Şekil 1a).
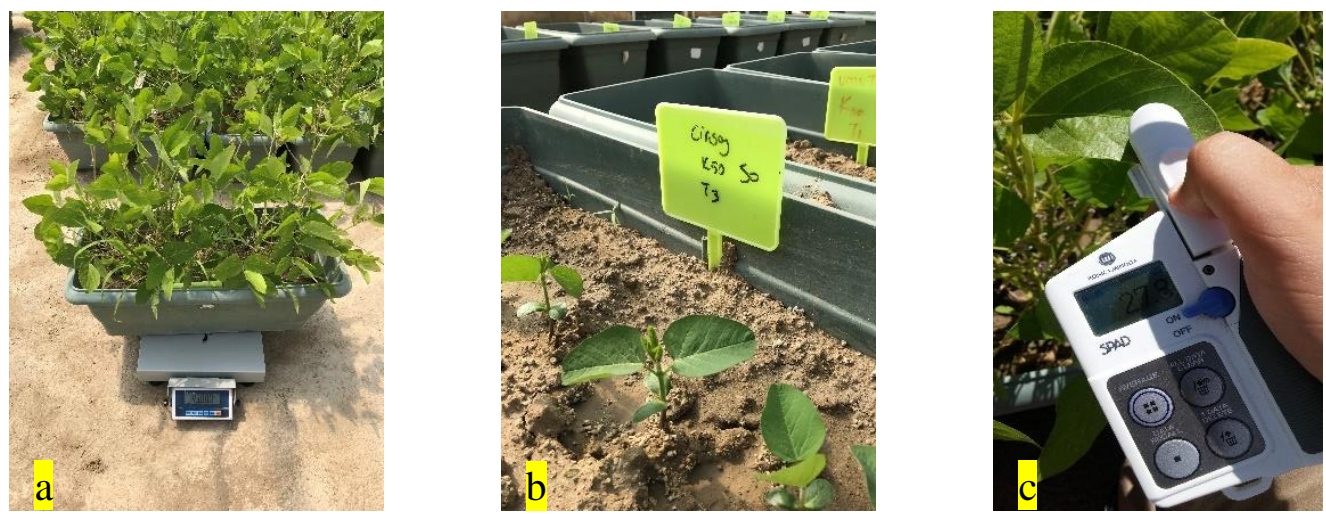

Şekil 1. Saksılarda sulama için günlük tartım (a), yetiştirilen bitkilerin görünümü (b), yaprak klorofil (SPAD) ölçümü (c)

Ayrıca diğer bir faktör olarak kükürtlü gübre dozu $0 \mathrm{~kg} / \mathrm{da}\left(\mathrm{K}_{0}\right.$; kontrol) ve $5 \mathrm{~kg} / \mathrm{da}\left(\mathrm{K}_{5}\right)$ dozları uygulanarak kükürtlü gübreleme jips şeklinde uygulanmıştır. 
Denemede iki yıl boyunca tesadüf parselleri deneme desenine uygun olacak şekilde 3 tekerrürlü ve tarla kapasitesi su uygulamaları, çeşit ve kükürt dozları faktörleri ile toplam 72 adet saksıda yürütülmüsstür (Şekil 1b). Taban gübresi olarak ekim öncesi bitkinin fosfor ihtiyacını da dikkate alarak, dekara $3.2 \mathrm{~kg}$ saf azot gelecek şekilde DAP gübresi uygulanmıştır. Ekimden hemen önce tohumlara simbiyotik azot tespitinin gerçekleşebilmesi amaciyla Bradyrhizobium japonicum bakterisi aşılanmıştır.

Bakla bağlama (BBCH 75) ve tane dolum (BBCH 85) dönemlerinde iki ayrı zamanda her bir bitkide toplam 15 yaprakçıkta Konica Minolta SPAD 502 cihazı ile yaprak klorofil içeriği değişimi belirlenmiştir (Şekil 1c). Hasat döneminde her bir saksıda bulunan bitkiler kök boğazından hasat edilerek bitki boyu, ilk bakla yüksekliği, bitkide bakla sayısı, baklada tane sayısı, bin tane ağırlı̆̆ı, tek bitki verimi parametreleri tespit edilmiştir. Elde edilen veriler tesadüf parselleri deneme desenine uygun olarak varyans analizine tabi tutulmuştur. Ortalamaların karşılaştırılmasında ve istatistiki farklı gruplar LSD testi ile belirlenmiştir (Açıkgöz ve ark., 2004).

\section{Bulgular ve Tartışma}

Saksı çalışmamızda iki farklı deneme yılında farklı su ve kükürt gübre uygulamalarının soya çeşitlerinin incelenen parametrelere ilişkin varyans analiz sonuçları Çizelge 2.'de verilmiştir. Yı1, Su dozu uygulamaları, YılxSu interaksiyonu ve Çeşit faktörleri tüm özellikler bakımından istatistiki düzeyde önemli farklılıklara neden olmuştur. Kükürt gübre dozu uygulamaları ise incelenen özelliklerin genelinde bir fark ortaya çıkartmazken, tane dolum dönemi klorofil içeriği ile bitkide yaprak alan miktarı üzerine önemli düzeyde etki etmiştir. YılxSuxÇeşitxKükürt interaksiyonu ise bitki boyu, ilk bakla yüksekliği, bitkide bakla sayısı, bin tane ağırlığı, tek bitki verimi, yaprak klorofil içeriği üzerinde istatistiksel anlamda önemli farkl11ıklara neden olmuştur.

Çizelge 2. İncelenen özelliklere ait istatistiksel önemlilik düzeyleri

\begin{tabular}{|c|c|c|c|c|c|c|c|c|}
\hline VK & SD & $\mathrm{BOY}$ & İBY & BBS & BTA & TBV & SPAD $_{1}$ & $\mathrm{SPAD}_{2}$ \\
\hline Y1l (Y) & 1 & $* *$ & $* *$ & $* *$ & $* *$ & $* *$ & $* *$ & $* *$ \\
\hline $\mathrm{Su}(\mathrm{S})$ & 3 & $* *$ & $* *$ & $* *$ & $* *$ & $* *$ & $* *$ & $* *$ \\
\hline YxS & 3 & $* *$ & $*$ & $*$ & $* *$ & $* *$ & $* *$ & $* *$ \\
\hline Çeşit (Ç) & 2 & $* *$ & $* *$ & $* *$ & $* *$ & $*$ & $* *$ & $*$ \\
\hline YxÇ & 2 & $* *$ & $* *$ & $* *$ & $* *$ & $* *$ & $* *$ & öd \\
\hline $\mathrm{SxÇ}$ & 6 & $* *$ & $*$ & $* *$ & $* *$ & $* *$ & $* *$ & $* *$ \\
\hline YxSxÇ & 6 & $* *$ & $* *$ & öd & $* *$ & $*$ & öd & $* *$ \\
\hline Kükürt (K) & 1 & öd & öd & öd & öd & öd & öd & $* *$ \\
\hline YxK & 1 & öd & öd & öd & öd & öd & öd & $* *$ \\
\hline SxK & 3 & öd & $*$ & öd & $* *$ & $*$ & $*$ & $* *$ \\
\hline YxSxK & 3 & öd & $*$ & öd & $*$ & öd & $* *$ & $*$ \\
\hline ÇxK & 2 & öd & öd & öd & $* *$ & $* *$ & öd & öd \\
\hline YxCXK & 2 & öd & öd & öd & öd & öd & öd & $* *$ \\
\hline SxCxK & 6 & öd & $* *$ & $*$ & $*$ & $*$ & $*$ & öd \\
\hline YxSxÇxK & 6 & $* *$ & $*$ & $* *$ & $* *$ & $* *$ & $* *$ & $* *$ \\
\hline
\end{tabular}

VK: Varyasyon kaynăğ; SD: Serbestlik Derecesi; BBS: Bitkide bakla sayısı; BTS: Baklada tane sayısı; BTA: Bin tane ağırlı̆̆ı; TBV: Tek bitki verimi; $\mathrm{SPAD}_{1}$ : Bakla bağlama dönemi klorofil içeriği; $\mathrm{SPAD}_{2}$ : Tane dolum dönemi klorofil içeriği; öd: önemli değil, *: 0,05 düzeyinde, **: 0,01 düzeyinde önemli

\section{Bitki Boyu (cm)}

Çalışmanın iki farklı yılında soya çeşitlerinin farklı su ve kükürt gübre dozlarında bitki boyu $35.98 \mathrm{~cm}$ ile $94.90 \mathrm{~cm}$ arasında değişim göstermiştir. En kısa soya fasulyesi bitkisi 2017 deneme yılında Arısoy çeşidinde $\mathrm{TK}_{\% 50}$ sulama dozunda ve $\mathrm{K}_{5}$ kükürt gübre dozunda saptanmıştır. 2017 deneme yılında $\mathrm{TK}_{\% 25}$ sulama dozunda $\mathrm{TK}_{\% 50}$ sulama dozuna göre daha yüksek bitki boyları elde edilmesine karşın bu durum 2018 deneme yılında tersi olmuştur, ancak her iki yılın ortalaması sonucu $\mathrm{TK}_{\% 25}$ sulama dozunda daha yüksek bitki boyları ölçülmüştür. En yüksek bitki boyu 2018 deneme yılında Arısoy çeşidinde $\mathrm{TK}_{\% 100}$ sulama dozunda $\mathrm{K}_{0}$ kükürt dozunda ölçülmüştür (Çizelge 3). Saksı denemesinde çeşitler arasında da önemli farklar bulunmuştur. Umut-2002 ve Cinsoy çeşitleri Arısoy çeşidinden önemli oranda daha yüksek bitki boyuna sahip olmuştur. En kısa bitki boyuna ortalama $61.30 \mathrm{~cm}$ ile Arısoy çeşidi sahip olmuştur ve diğer iki çeşitten istatistiki olarak daha kısa bulunmuştur. 
Çizelge 3. Bitki boyuna ait ortalama değerler (cm)

\begin{tabular}{|c|c|c|c|c|c|c|c|}
\hline \multirow{2}{*}{\multicolumn{2}{|c|}{ Yıl/Kükürt/Çeşit/Su }} & \multicolumn{3}{|c|}{$K_{0 \mathrm{~kg} / \mathrm{da}}$} & \multicolumn{3}{|c|}{$K_{5 \mathrm{~kg} / \mathrm{da}}$} \\
\hline & & Cinsoy & Arisoy & Umut-2002 & Cinsoy & Arisoy & Umut-2002 \\
\hline \multirow[t]{4}{*}{2017} & $\mathrm{TK}_{\% 25}$ & $59.16 \mathrm{k}-\mathrm{n}$ & $49.83 \mathrm{p}-\mathrm{t}$ & $53.25 \mathrm{n}-\mathrm{s}$ & $57.021-\mathrm{o}$ & $54.42 \mathrm{~m}-\mathrm{q}$ & $56.19 \mathrm{mno}$ \\
\hline & $\mathbf{T K}_{\% 50}$ & $41.15 \mathrm{vy}$ & $40.87 \mathrm{vy}$ & 44.39 tuv & 43.26 tuv & $35.98 \mathrm{z}$ & $47.69 \mathrm{stu}$ \\
\hline & $\mathbf{T K}_{\% 75}$ & $66.25 \mathrm{~h} 1 \mathrm{j}$ & $51.860-\mathrm{t}$ & $47.31 \mathrm{tu}$ & $65.141-\mathrm{k}$ & $49.04 \mathrm{q}-\mathrm{u}$ & $53.34 \mathrm{n}-\mathrm{s}$ \\
\hline & $\mathbf{T K}_{\% 100}$ & $75.27 \mathrm{efg}$ & $57.34 \mathrm{k}-\mathrm{o}$ & $55.46 \mathrm{~m}-\mathrm{p}$ & $69.27 \mathrm{~h} 1$ & 53.44 n-r & $57.57 \mathrm{k}-\mathrm{o}$ \\
\hline \multirow[t]{4}{*}{2018} & $\mathbf{T K}_{\% 25}$ & $57.50 \mathrm{k}-\mathrm{o}$ & $57.40 \mathrm{k}-\mathrm{o}$ & $65.75 \mathrm{iij}$ & $62.32 \mathrm{i}-1$ & $59.87 \mathrm{j}-\mathrm{m}$ & 69.70 gh1 \\
\hline & $\mathbf{T K}_{\% 50}$ & 70.59 ghı & $63.03 \mathrm{ijk}$ & $76.56 \mathrm{ef}$ & $66.82 \mathrm{~h} 1 \mathrm{j}$ & $63.25 \mathrm{ijk}$ & $78.26 \mathrm{e}$ \\
\hline & $\mathbf{T K}_{\% 75}$ & $72.14 \mathrm{fgh}$ & $79.36 \mathrm{de}$ & $84.36 \mathrm{~cd}$ & $76.70 \mathrm{ef}$ & $78.30 \mathrm{e}$ & $87.73 \mathrm{bc}$ \\
\hline & TK\%100 & $85.16 \mathrm{~cd}$ & $94.90 \mathrm{a}$ & $88.47 \mathrm{bc}$ & $78.36 \mathrm{e}$ & $91.96 \mathrm{ab}$ & $92.10 \mathrm{ab}$ \\
\hline
\end{tabular}

Lsd Y1l: 1.71; Lsd Su: 2.41; Lsd YılxSu: 3.42; Lsd Çeşit: 2.09; Lsd Y1lxÇeşit: 2.96; Lsd SuxÇeşit: 4.18; Lsd Y1lxSuxÇeşit: 5.92

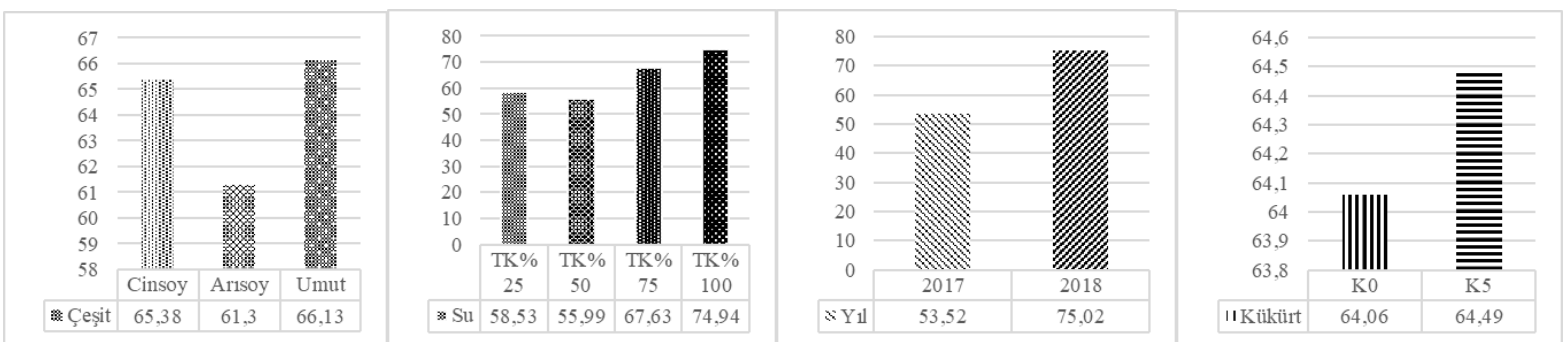

Şekil 2. Çeşit, Su dozu, yıl ve kükürt dozu uygulamalarına ait bitki boyu ortalama değerleri (cm)

Artan sulama dozlarının bitki boyu üzerine önemli ve pozitif etkisi görülmüştür. Özellikle $\mathrm{TK}_{\% 75}$ ve $\mathrm{TK}_{\% 100}$ sulama dozlarında bitki önemli oranda artışlar meydana getirmiştir. En yüksek ortalama bitki boyu saksı koşullarında $74.94 \mathrm{~cm}$ ile en yüksek sulama dozu olan $\mathrm{TK}_{\% 100}$ sulama dozunda ölçülmüştür. Sulama dozunun $\mathrm{TK}_{\% 50}$ 'nin üzerine çıkarılması ile bitki boylarında önemli ve belirgin artışlar kaydedilmiştir (Şekil 2). Kükürt uygulaması sonucu ortalama daha yüksek bitki boyu meydana gelmesine rağmen elde edilen fark istatistiki olarak önemli bulunmamıştır. Ünal (2007); Ege Bölgesi koşullarında tarla şartlarında yürütülen bir çalışmada soya fasulyelerine ait bitki boylarının $90.7 \mathrm{~cm}$ ile $119.0 \mathrm{~cm}$ arasında değiştiğini ve yaptığımız farklı uygulamaların bitki boyu üzerine elde edilen bulgularla benzer olduğu görülmüsşür. Kaya ve ark. (2017)'nın sera koşullarında yürüttükleri bir çalışmada ise bitki boylarının $70.6 \mathrm{~cm}$ ile $90.6 \mathrm{~cm}$ arasında olduğunu ve elde ettiğimiz sonuçlar ile uyumlu olduğu tespit edilmiş̧ir. Kısıtlı sulama koşullarında $\left(\mathrm{TK}_{\% 25}, \mathrm{TK}_{\% 50}\right)$ bitki boyunun önemli ölçüde azalarak bu değerlerin altında kaldığı yeterli oranda toprak nemi bulunmayan koşullarda bitki boyunda önemli azalmalar olacă̆ anlaşılmaktadır.

\section{İlk Bakla Yüksekliği (cm)}

Saksı denemesinin iki farklı yılında soya çeşitlerin farklı su ve kükürt gübre dozlarında ilk bakla yükseklikleri $9.71 \mathrm{~cm}$ ile $26.60 \mathrm{~cm}$ arasında değişim göstermiştir ve farklı uygulamalar arasında önemli farklar ortaya çıkmıştır. En kısa ilk bakla yüksekliği 2018 deneme yılında Arısoy çeşidinde $\mathrm{TK}_{\% 50}$ sulama dozunda ve $\mathrm{K}_{5}$ kükürt gübre dozunda saptanmıştır. En yüksek ilk bakla yüksekliği ise 2018 y1lında, Umut-2002 çeşidinde $\mathrm{TK}_{\% 100}$ sulama dozunda ve $\mathrm{K}_{0}$ kükürt gübre dozunda ölçülmüştür. Çeşitler arasında Umut-2002 ve Cinsoy çeşitlerinin ilk bakla yükseklikleri Arısoy çeşidinden önemli oranda daha yüksek bulunmuştur. Umut-2002 ve Cinsoy çeşitleri aynı istatistiki grupta yer almıştır. Sulama dozları ilk bakla yüksekliklerinin önemli oranda değişmesine neden olmuştur. Sulama dozlarına bağlı olarak ilk bakla yükseklikleri $15.72 \mathrm{~cm}$ ile $20.84 \mathrm{~cm}$ arasında değişmiştir. En yüksek değer (20.84 cm ) TK\%100 sulama dozunda tespit edilmiştir (Çizelge 4, Şekil 3). 
Çizelge 4. İlk bakla yüksekliğine ait ortalama değerler $(\mathrm{cm})$

\begin{tabular}{|c|c|c|c|c|c|c|c|}
\hline \multirow{2}{*}{\multicolumn{2}{|c|}{ Yıl/Kükürt/Çeşit/Su }} & \multicolumn{3}{|c|}{$K_{0 \mathrm{~kg} / \mathrm{da}}$} & \multicolumn{3}{|c|}{$K_{5} \mathrm{~kg} / \mathrm{da}$} \\
\hline & & Cinsoy & Arisoy & Umut-2002 & Cinsoy & Arisoy & Umut-2002 \\
\hline \multirow[t]{4}{*}{2017} & $\mathrm{TK}_{\% 25}$ & $16.80 \mathrm{k}-\mathrm{q}$ & $20.80 \mathrm{~d}-1$ & $22.69 \mathrm{~b}-\mathrm{g}$ & $16.111-\mathrm{r}$ & $19.91 \mathrm{f}-\mathrm{k}$ & $23.82 \mathrm{a}-\mathrm{d}$ \\
\hline & $\mathbf{T K}_{\% 50}$ & $16.59 \mathrm{k}-\mathrm{r}$ & $14.22 \mathrm{o}-\mathrm{s}$ & $20.42 \mathrm{e}-\mathrm{j}$ & $15.84 \mathrm{n}-\mathrm{r}$ & $17.14 j-q$ & $16.45 \mathrm{k}-\mathrm{r}$ \\
\hline & $\mathbf{T K}_{\% 75}$ & $20.33 \mathrm{e}-\mathrm{j}$ & 23.73 a-e & $17.391-p$ & $19.28 \mathrm{~g}-\mathrm{m}$ & $17.731-\mathrm{o}$ & $22.61 \mathrm{~b}-\mathrm{g}$ \\
\hline & TK $_{\% 100}$ & $22.72 \mathrm{~b}-\mathrm{g}$ & $19.05 \mathrm{~h}-\mathrm{m}$ & 25.22 abc & $25.81 \mathrm{ab}$ & $22.05 \mathrm{c}-\mathrm{h}$ & $23.31 \mathrm{a}-\mathrm{f}$ \\
\hline \multirow[t]{4}{*}{2018} & $\mathbf{T K}_{\% 25}$ & $14.58 \mathrm{o}-\mathrm{s}$ & $11.55 \mathrm{st}$ & $15.31 \mathrm{n}-\mathrm{r}$ & $14.56 \mathrm{o}-\mathrm{s}$ & $14.26 \mathrm{o}-\mathrm{s}$ & $18.86 \mathrm{~h}-\mathrm{m}$ \\
\hline & $\mathbf{T K}_{\% 50}$ & $17.481-\mathrm{p}$ & 14.26 o-s & $18.351-n$ & 13.74 qrs & $9.71 \mathrm{t}$ & $14.49 \mathrm{o}-\mathrm{s}$ \\
\hline & $\mathrm{TK}_{\% 75}$ & $14.51 \mathrm{o}-\mathrm{s}$ & $13.43 \mathrm{rs}$ & $16.73 \mathrm{k}-\mathrm{r}$ & $14.73 \mathrm{o}-\mathrm{s}$ & $13.58 \mathrm{rs}$ & $18.431-n$ \\
\hline & TK\%100 & $17.601-0$ & $14.07 \mathrm{p}-\mathrm{s}$ & $26.60 \mathrm{a}$ & $16.001-\mathrm{r}$ & $18.201-\mathrm{n}$ & $19.50 \mathrm{~g}-1$ \\
\hline
\end{tabular}

Lsd Y1l: 0.71; Lsd Su: 1.01; Lsd Y1lxSu: 1.43; Lsd Çeşit: 0.87; Lsd Y1lxÇeşit: 1.24; Lsd SuxÇeşit: 1.75; Lsd Y1lxSuxÇeşit: 2.48; Lsd SuxKükürt: 1.43; Lsd YılxSuxKükürt: 2.02; Lsd SuxÇeşitxKükürt: 2.48; Lsd Y1lxSuxÇeşitxKükürt: 3.51

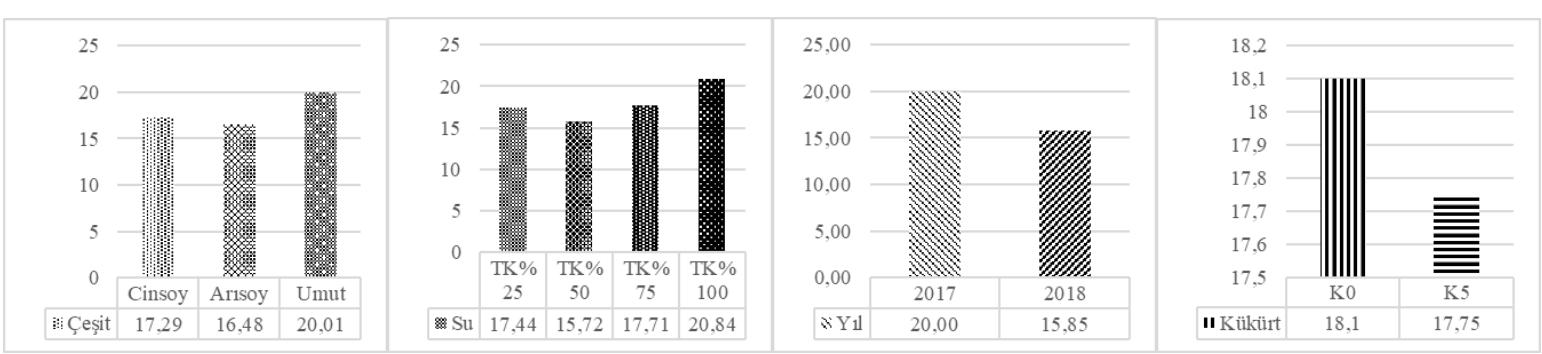

Şekil 3. Çeşit, Su dozu, Yıl ve Kükürt dozu uygulamalarına ait ilk bakla yüksekliği ortalama değerleri $(\mathrm{cm})$

Bitki boyunda olduğu gibi ilk bakla yüksekliğinde de $\mathrm{TK}_{\% 25}$ sulama dozunda $\mathrm{TK}_{\% 50}$ sulama dozuna göre daha yüksek değerler elde edilmiştir. Kükürt gübre uygulamasının soya fasulyesi çeşitlerinde ilk bakla yüksekliği üzerine önemli bir etkisi tespit edilmemiştir. Sıcaklık ortalamasının soya fasulyesi için düşük olduğu ekolojik koşullarda Ataem-7 çeşidinde ilk bakla yüksekliğini $31.2 \mathrm{~cm}$ olarak belirlenmiştir (Boydak ve ark. 2018). Farklı agronomik uygulamaların ilk bakla yüksekliği üzerine elde edilen bulguların Doğan ve ark. (2015) ve Dede ve Acar (2019)'ın yaptıkları çalı̧̧malardan daha yüksek ancak $\mathrm{TK}_{\% 25}$ sulama dozunda elde edilen sonuçlarla büyük ölçüde benzer olduğu görülmüştür. İlk bakla yüksekliği özellikle genetik özelliklere bağlı olarak değişmekle birlikte üç farklı lokasyonda, 14 farklı genotipte $6.8-12.5 \mathrm{~cm}$ arasında geniş bir aralıkta değişmiştir. Ayrıca Arısoy çeşidi 11 farklı çevre koşulunda $8.3 \mathrm{~cm}$ değerini alarak birçok soya hat ve çeşidinden daha düşük değer almıştır (Kocaturk ve ark., 2019). Ege Bölgesi koşullarında yapılan bir çalışmada soya fasulyesi çeşit ve hatlarının ilk bakla yüksekliği değerleri 3.6-11.9 cm değerleri arasında değişerek çalışmamızda oldukça yüksek değerler elde edilmiştir. Çalışmada kullanılan Arısoy çeşidinin ilk bakla yüksekliği ortalama değeri ise $5.4 \mathrm{~cm}$ olarak bulunarak çalışmamızda daha yüksek değerler alınmıştır (İlker, 2017).

Genel olarak; Yıl, Su ve Çeşit faktörlerinin önemli olduğu ilk bakla yüksekliğinde özellikle Umut-2002 çeşidinin yükssek değerler aldığ 1 ve $\mathrm{TK}_{\% 100}$ sulama dozunda $\mathrm{TK}_{\% 75}$ sulama dozuna göre önemli oranda daha yüksek ilk bakla yüksekliği saptanmıştır. Artan sulama dozların etkisinin bitki boyuna katkısı ile ilk bakla yüksekliğine de pozitif etki yaptı̆̆ı anlaşılmaktadır.

Bitkide Bakla Sayısı (adet)

Verim öğelerinden bitkide bakla sayısı soya fasulyesinde tane verimin oluşmasında ve belirlenmesinde önemli bir özelliktir (Yıldırım ve ark., 2020). Saksı denemesinin iki farklı deneme yılında soya çeşitlerin farklı su ve kükürt gübre dozlarında bir bitkide baklada tane sayıları 21.86 adet ile 59.70 adet arasında değişim göstermiştir ve farklı uygulamalar arasında büyük ve önemli farklar ortaya çıkmıştır. En düşük bitkide bakla sayısı 2018 deneme yılında Umut-2002 çeşidinde $\mathrm{TK}_{\% 25}$ sulama dozunda ve $\mathrm{K}_{5}$ kükürt gübre dozunda tespit edilmiştir. En yüksek değer ise yaklaşık üç katı bir değer ile 2018 deneme yılında Arısoy çeşidinde $\mathrm{TK}_{\% 100}$ sulama dozunda ve $\mathrm{K}_{5}$ kükürt gübre uygulamasında ölçülmüştür (Çizelge 5). 
Çizelge 5. Bitkide bakla sayısına ait ortalama değerler (adet/bitki)

\begin{tabular}{|c|c|c|c|c|c|c|c|}
\hline \multirow{2}{*}{\multicolumn{2}{|c|}{ Yıl/Kükürt/Çeşit/Su }} & \multicolumn{3}{|c|}{$K_{0 \text { kg/da }}$} & \multicolumn{3}{|c|}{$K_{5 \mathrm{~kg} / \mathrm{da}}$} \\
\hline & & Cinsoy & Arisoy & Umut-2002 & Cinsoy & Arisoy & Umut-2002 \\
\hline \multirow[t]{4}{*}{2017} & $\mathrm{TK}_{\% 25}$ & $28.15 \mathrm{r}-\mathrm{u}$ & $29.640-\mathrm{t}$ & $27.13 \mathrm{~s}-\mathrm{v}$ & $23.11 \mathrm{uv}$ & $33.20 \mathrm{j}-\mathrm{s}$ & 25.82 tuv \\
\hline & $\mathbf{T K}_{\% 50}$ & $34.83 \mathrm{i}-\mathrm{q}$ & $30.88 n-t$ & $39.08 \mathrm{f}-\mathrm{j}$ & $29.67 \mathrm{o}-\mathrm{t}$ & $35.441-0$ & $37.93 \mathrm{~g}-1$ \\
\hline & $\mathrm{TK}_{\% 75}$ & $33.21 \mathrm{j}-\mathrm{s}$ & $31.20 \mathrm{~m}-\mathrm{t}$ & $36.87 \mathrm{~h}-\mathrm{n}$ & $37.43 \mathrm{~g}-\mathrm{m}$ & $29.13 \mathrm{p}-\mathrm{u}$ & $31.861-\mathrm{t}$ \\
\hline & TK $_{\% 100}$ & $37.55 \mathrm{~g}-1$ & $52.16 \mathrm{bc}$ & $41.46 \mathrm{~d}-1$ & $42.98 \mathrm{~d}-\mathrm{h}$ & $43.55 \mathrm{~d}-\mathrm{g}$ & $38.55 \mathrm{f}-\mathrm{k}$ \\
\hline \multirow[t]{4}{*}{2018} & $\mathrm{TK}_{\% 25}$ & $28.80 \mathrm{q}-\mathrm{u}$ & $38.26 \mathrm{~g}-\mathrm{k}$ & $30.16 \mathrm{o}-\mathrm{t}$ & $33.22 \mathrm{j}-\mathrm{s}$ & $33.00 \mathrm{j}-\mathrm{s}$ & $21.86 \mathrm{v}$ \\
\hline & $\mathbf{T K}_{\% 50}$ & $42.13 \mathrm{~d}-\mathrm{h}$ & $34.13 \mathrm{i}-\mathrm{r}$ & $32.95 \mathrm{k}-\mathrm{s}$ & $41.40 \mathrm{~d}-1$ & $40.50 \mathrm{e}-\mathrm{i}$ & $31.731-\mathrm{t}$ \\
\hline & $\mathbf{T K}_{\% 75}$ & $46.93 \mathrm{~cd}$ & $41.13 \mathrm{~d}-1$ & $32.98 \mathrm{j}-\mathrm{s}$ & $42.50 \mathrm{~d}-\mathrm{h}$ & $41.33 \mathrm{~d}-1$ & $35.331-p$ \\
\hline & $\mathrm{TK}_{\% 100}$ & $44.56 \mathrm{def}$ & $56.19 \mathrm{ab}$ & $45.72 \mathrm{de}$ & $52.70 \mathrm{bc}$ & $59.70 \mathrm{a}$ & $41.53 \mathrm{~d}-1$ \\
\hline
\end{tabular}

Lsd Y1l: 1.27; Lsd Su: 1.80; Lsd Y11xSu: 2.55; Lsd Çeşit: 1.56; Lsd Y1lxÇeşit: 2.21; Lsd SuxÇeşit: 3.12; Lsd SuxÇeşitxKükürt: 4.42; Lsd Y1lxSuxÇeşitxKükürt: 6.25
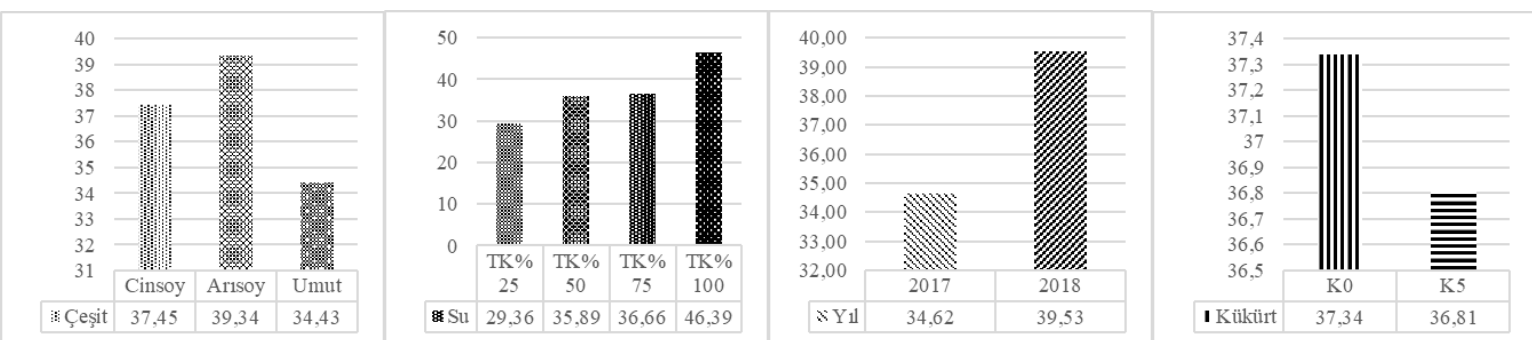

Şekil 4. Çeşit, Su dozu, Yıl ve Kükürt dozu uygulamalarına ait bitkide bakla sayısına ait ortalama değerleri (cm)

Çeşitler arasında bitkide bakla sayısı bakımından önemli farklar ortaya çıkmıştır. En yüksek bitkide bakla sayısı diğer çeşitlere kıyasla daha yüksek bir değer ile Arısoy çeşidinde saptanmıştır. En düşük bakla sayısı ise Umut-2002 çeşidinde ölçülmüştür. Artan sulama dozları bitkide bakla sayısının önemli oranda artmasına neden olmuştur.

Sulama dozları içerisinde en düşük değer $\mathrm{TK}_{\% 25}$ sulama dozunda ölçülmüştür. $\mathrm{TK}_{\% 50}, \mathrm{TK}_{\% 75}$ ve $\mathrm{TK}_{\% 100}$ sulama dozunda bakla sayıs1 $\mathrm{TK}_{\% 25}$ sulama dozundan önemli oranda daha yüksek bulunmuştur. Ancak $\mathrm{TK}_{\% 50}$ ve $\mathrm{TK}_{\% 75}$ sulama dozlarında bakla sayısı istatistiki olarak aynı olmuştur ve aynı grupta yer almıştır. Tarla kapasitesinde yapılan sulama dozunda bakla sayısı diğer uygulamalara oranla ciddi oranda artmıştır. İlave kükürt gübre uygulamasının herhangi pozitif ve önemli bir etkisi gözlenmemiştir (Şekil 4). Choudhary ve ark. (2014)'nın yaptıkları saksı çalışmasında bitkide bakla sayısı değerlerinin 9.4-12.5 adet/bitki arasında değiştiği belirtilerek çalışmamızda elde edilen değerlerin oldukça yüksek olduğu anlaşılmaktadır ancak araştırıcılar bitki boyu, bitkide dal sayısı, bitkide bakla sayısı ve 100 tane ağırlığı değerlerinin kükürtlü gübre uygulamalarında artış gösterdiğini belirtmişlerdir. Saksı koşullarında farklı soya çeşitlerinin bitkide bakla sayısı üzerine uygulanan farklı faktörlerden sulama dozlarının önemli ve pozitif etkisi tespit edilmiştir. Farklı uygulamalar sonucu elde edilen bulguların bitkide bakla sayısı üzerine özellikle $\mathrm{TK}_{\% 50}$ sulama dozu ve üzerinde genel olarak Hu ve Wiatrale (2012) ve Onat ve ark. (2017) ile benzer olduğu görülmüştür. Ege Bölgesi koşullarında yürütülen bir çalışmada ise soya hat ve çeşitlerinin bitkide bakla sayısı değerleri 31.559.3 adet arasında değişmekle birlikte, Umut-2002 çeşidi 46.3 adet ortalama değeri almıştır. Araştırmada bitkide bakla sayısının genotip faktörüne bağlı olarak değişmediği tespit edilmiş ve çalışmamızda elde edilen değerlerden daha yüksek sonuçlara ulaşılmıştır (Tuğay ve Atikyılmaz, 2009). Ancak Ma ve Sonoko (2019) tarafindan yapılan bir çalışmada sulama uygulamaların soya fasulyesinde bitkide bakla sayısını önemli ölçüde artırdığını ve ortaya konulan sonuçların bulgularımız ile uyumlu olduğu söylenebilmektedir.

\section{Bin Tane Ağırlı̆̆ı (g)}

Saksı çalışmasında elde edilen en düşük bin tane ağırlığı 63.39 g ile 2017 deneme yılında Cinsoy çeşidinde $\mathrm{TK}_{\% 25}$ sulama dozunda $\mathrm{K}_{5}$ kükürt gübre dozunda saptanmıştır. Buna karşın en yüksek bin tane ağırlığı 2017 deneme yılında Umut-2002 çeşidinde $\mathrm{TK}_{\% 75}$ sulama dozunda ve $\mathrm{K}_{0}$ kükürt gübre dozunda ölçülmüştür (Çizelge 6). 
Çizelge 6. Bin tane ağırlı̆̆ına ait ortalama değerler (g)

\begin{tabular}{|c|c|c|c|c|c|c|c|}
\hline \multirow{2}{*}{\multicolumn{2}{|c|}{ Yıl/Kükürt/Çeşit/Su }} & \multicolumn{3}{|c|}{$K_{0 \mathrm{~kg} / \mathrm{da}}$} & \multicolumn{3}{|c|}{$K_{5} \mathrm{~kg} / \mathrm{da}$} \\
\hline & & Cinsoy & Arisoy & Umut-2002 & Cinsoy & Arisoy & Umut-2002 \\
\hline \multirow[t]{4}{*}{2017} & $\mathrm{TK}_{\% 25}$ & $75.28 \mathrm{r}$ & $77.62 \mathrm{r}$ & 94.55 1-o & $63.39 \mathrm{~s}$ & $75.42 \mathrm{r}$ & $78.03 \mathrm{qr}$ \\
\hline & $\mathrm{TK}_{\% 50}$ & $102.30 \mathrm{e}-\mathrm{i}$ & $100.16 \mathrm{~g}-\mathrm{k}$ & $117.95 \mathrm{bc}$ & $95.101-n$ & $90.231-p$ & $128.30 \mathrm{a}$ \\
\hline & TK $_{\% 75}$ & 92.75 i-o & $81.55 \mathrm{pqr}$ & $119.40 \mathrm{ab}$ & $90.80 \mathrm{k}-\mathrm{p}$ & $99.30 \mathrm{~h}-1$ & $101.71 \mathrm{f}-\mathrm{j}$ \\
\hline & TK $_{\% 100}$ & $92.29 \mathrm{j}-\mathrm{o}$ & $103.11 \mathrm{e}-1$ & $99.35 \mathrm{~h}-1$ & $95.271-n$ & $101.78 \mathrm{f}-\mathrm{j}$ & $118.32 \mathrm{bc}$ \\
\hline \multirow[t]{4}{*}{2018} & $\mathbf{T K}_{\% 25}$ & $85.33 \mathrm{opq}$ & $94.561-0$ & $94.801-0$ & 87.90 nop & $94.40_{1-0}$ & $92.73 \mathrm{i}-\mathrm{o}$ \\
\hline & $\mathrm{TK}_{\% 50}$ & $98.90 \mathrm{~h}-\mathrm{m}$ & $87.33 n-q$ & $103.00 \mathrm{e}-1$ & $95.801-\mathrm{n}$ & $102.30 \mathrm{e}-\mathrm{i}$ & $104.06 \mathrm{~d}-1$ \\
\hline & $\mathbf{T K}_{\% 75}$ & 99.13 h-m & $99.96 \mathrm{~g}-\mathrm{k}$ & $116.33 \mathrm{bc}$ & $89.60 \mathrm{~m}-\mathrm{p}$ & $99.40 \mathrm{~h}-1$ & $111.93 \mathrm{~b}-\mathrm{e}$ \\
\hline & $\mathbf{T K}_{\% 100}$ & $106.53 \mathrm{~d}-\mathrm{h}$ & $94.561-0$ & $117.60 \mathrm{bc}$ & $109.10 \mathrm{c}-\mathrm{g}$ & $111.30 \mathrm{~b}-\mathrm{f}$ & $113.70 \mathrm{bcd}$ \\
\hline
\end{tabular}

Lsd Y11: 1.97; Lsd Su: 2.79; Lsd Y11xSu: 3.95; Lsd Çeşit: 2.42; Lsd Yı1xÇeşit: 3.42; Lsd Yı1xSuxÇeşit: 6.85; Lsd SuxKükürt: 3.95; Lsd YılxSuxKükürt: 5.59; Lsd ÇeşitxKükürt: 3.42; Lsd SuxÇeşitxKükürt: 6.85; Lsd Y1lxSuxÇeşitxKükürt: 9.68

Farklı uygulamalar arasında bin tane ağırlı̆̆ bakımından önemli ve büyük farklar meydana gelmiştir. Çeşitlerin bin tane ağırlıkları önemli farklılıklar ortaya koymuştur. Umut-2002 çeşidi denemedeki diğer iki çeşitten önemli oranda daha yüksek ortalama bin tane ağırlığına sahip olmuştur. Cinsoy ve Arısoy çeşitleri ise bin tane ağırlığı bakımından aynı istatistiki grupta yer almıştır.

Artan sulama dozları bin tane ağırlığının artmasına neden olmuştur. En düşük bin tane ağırlığ 1 ortalama $84.5 \mathrm{~g}$ ile $\mathrm{TK}_{\% 25}$ sulama dozunda ölçülmüştür. $\mathrm{TK}_{\% 50}$ ve $\mathrm{TK}_{\% 75}$ sulama dozlarının bin tane ağırlıkları $\mathrm{TK}_{\% 25}$ sulama dozundan önemli oranda daha yüksek bulunmuştur ve bu iki sulama dozu aynı istatistiki grupta yer almıştır. $\mathrm{TK}_{\% 100}$ sulama dozu ile bin tane ağırlıkları tekrar önemli oranda bir artış meydana getirmiştir ve çalışmada en yüksek değerler en üst seviyedeki sulama dozu ile elde edilmiştir. Muandemela ve ark. (2010)'nın 30 soya fasulyesi hattında yaptıkları bir çalışmada kuraklığın bitkide bakla sayısını ve baklada tohum sayısını olumsuz etkilediğini tane iriliğinin azaldığını ve tanelerin çimlenme özelliklerinin de olumsuz yönde etkilendiklerini bildirmiştir. Kükürt gübre uygulamasının pozitif ve önemli bir etkisi gözlenmemiştir (Şekil 5).

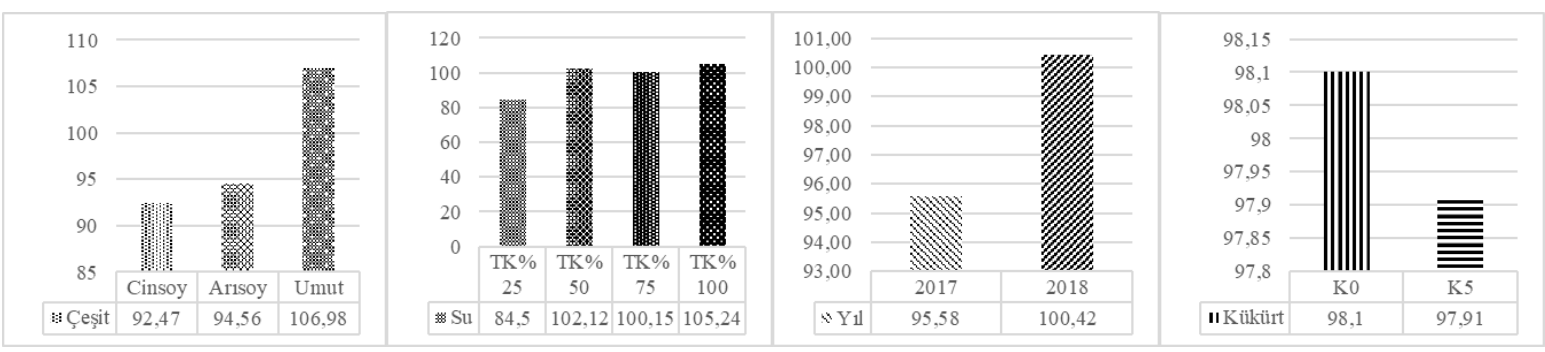

Şekil 5. Çeşit, Su dozu, Yıl ve Kükürt dozu uygulamalarına ait bin tane ağırlığı ortalama değerleri (g)

Yıldırım ve İlker (2018)'in Ege Bölgesi koşullarında yürüttükleri çalışmalarında soya fasulyesi bin tane ağırlığı değerlerinin genetik özelliklere bağlı olarak önemli oranda etkilendiği ve elde edilen ortalama değerlerin 137.75-229.12 g arasında değiştiğini belirterek çalışmamıza göre yüksek bin tane ağırlığı değerleri elde edilmiştir. Elde edilen değerler incelendiğinde genel olarak Onat vd. (2017) ve Ünal (2007) tarafından elde edilen bin tane ağırlıklarından düşük olduğu saptanmıştır.

\section{Tek Bitki Verimi (g)}

Soya fasulyesinde hava sıcaklığının $30^{\circ} \mathrm{C}$ 'nin üzerinde fotosentez aktivitesi azalmaktadır ve hava sıcaklığının $35^{\circ} \mathrm{C}$ 'nin üzerine çıkması ile çiçeklerde dökülmenin yüksek düzeylere ulaşabileceği belirtilmiştir. $\mathrm{Bu}$ dönemde verim kayıplarını belli bir ölçüde azaltabilmek için toprakta yeterli alınabilir suyun bulunması gerektiği vurgulanmıştır (Arığlu ve Güllüoğlu, 2019).

Çalışmada tek bitki verimi farklı uygulamalar nedeniyle önemli oranda değişmiştir. Tek bitki verimine ait en düşük değer 2017 deneme yılında $\mathrm{TK}_{\% 25}$ sulama dozunda Umut-2002 çeşidinde $\mathrm{K}_{5}$ kükürt gübre dozunda ölçülmüştür. Buna karşın en yüksek tek bitki verimi olan $18.66 \mathrm{~g}$ ise 2018 deneme yılında Arısoy çeşidinde $\mathrm{TK}_{\% 100}$ sulama dozunda ve $\mathrm{K}_{5}$ kükürt gübre dozunda belirlenmiştir (Çizelge 7). Çeşitler arasında da önemli farklar bulunmuştur. Cinsoy ve Arısoy çeşitleri aynı istatistiki grupta yer almıştır ve bu iki çeşit Umut-2002 çeşidinden önemli oranda daha yüksek tek bitki verimi meydana getirmiştir. 
Çizelge 7. Tek bitki verimine ait ortalama değerler (g/bitki)

\begin{tabular}{|c|c|c|c|c|c|c|c|}
\hline \multirow{2}{*}{\multicolumn{2}{|c|}{ Yıl/Kükürt/Çeşit/Su }} & \multicolumn{3}{|c|}{$\mathbf{K}_{0 \mathrm{~kg} / \mathrm{da}}$} & \multicolumn{3}{|c|}{$K_{5}$ kg/da } \\
\hline & & Cinsoy & Arisoy & Umut-2002 & Cinsoy & Arisoy & Umut-2002 \\
\hline \multirow[t]{4}{*}{2017} & $\mathrm{TK}_{\% 25}$ & $6.221-q$ & $5.28 \mathrm{o}-\mathrm{r}$ & $5.57 \mathrm{n}-\mathrm{q}$ & $4.42 \mathrm{pqr}$ & 5.37 o-r & $3.19 \mathrm{r}$ \\
\hline & $\mathrm{TK}_{\% 50}$ & $6.641-p$ & $6.651-p$ & 10.17 e-h & $7.32 \mathrm{j}-\mathrm{o}$ & $7.811-\mathrm{n}$ & $9.11 \mathrm{f}-\mathrm{j}$ \\
\hline & TK $_{\% 75}$ & $5.24 \mathrm{o}-\mathrm{r}$ & $4.57 \mathrm{pqr}$ & $10.52 \mathrm{efg}$ & $6.101-\mathrm{q}$ & $5.70 \mathrm{n}-\mathrm{q}$ & $6.81 \mathrm{k}-\mathrm{p}$ \\
\hline & TK $_{\% 100}$ & $8.95 \mathrm{f}-\mathrm{k}$ & $11.25 \mathrm{def}$ & $9.94 \mathrm{e}-\mathrm{i}$ & $10.76 \mathrm{def}$ & $10.55 \mathrm{efg}$ & $8.95 \mathrm{f}-\mathrm{k}$ \\
\hline \multirow[t]{4}{*}{2018} & TK $_{\% 25}$ & 5.33 o-r & 8.00 h-m & $5.66 \mathrm{n}-\mathrm{q}$ & $6.331-q$ & $6.00 \mathrm{~m}-\mathrm{q}$ & $4.33 \mathrm{qr}$ \\
\hline & $\mathrm{TK}_{\% 50}$ & $9.66 \mathrm{f}-\mathrm{i}$ & 8.00 h-m & $8.00 \mathrm{~h}-\mathrm{m}$ & $10.00 \mathrm{e}-1$ & $10.66 \mathrm{ef}$ & $7.66 \mathrm{i}-\mathrm{n}$ \\
\hline & $\mathbf{T K}_{\% 75}$ & 10.33 efg & $10.00 \mathrm{e}-1$ & $8.00 \mathrm{~h}-\mathrm{m}$ & $8.33 \mathrm{~g}-1$ & $10.00 \mathrm{e}-1$ & $8.33 \mathrm{~g}-1$ \\
\hline & $\mathbf{T K}_{\% 100}$ & $13.00 \mathrm{~cd}$ & $14.33 \mathrm{bc}$ & $12.00 \mathrm{de}$ & $18.66 \mathrm{a}$ & $15.66 \mathrm{~b}$ & $10.00 \mathrm{e}-1$ \\
\hline
\end{tabular}

Lsd Y11: 0.466. Lsd Su: 0.659; Lsd Y1lxSu: 0.932; Lsd Çeşit: 0.571; Lsd Y1lxÇeşit: 0.807; Lsd SuxÇeşit: 1.142; Lsd Y1lxSuxÇeşit: 1.615; Lsd SuxKükürt: 0.932; Lsd ÇeşitxKükürt: 0.807; Lsd SuxÇeşitxKükürt: 1.615; Lsd Y1lxSuxÇeşitxKükürt: 2.283

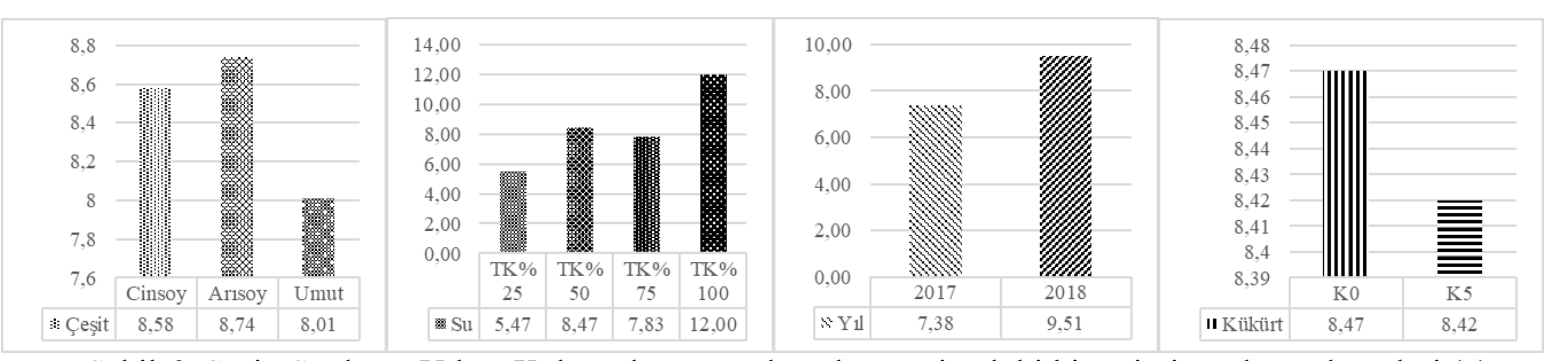

Şekil 6. Çeşit, Su dozu, Yıl ve Kükürt dozu uygulamalarına ait tek bitki verimi ortalama değerleri (g)

Sulama dozları arasında da önemli farklar ortaya çıkmıştır ve bu kapsamda artan sulama dozları tek bitki verimin artmasına neden olmuştur. En düşük tek bitki verimi $\mathrm{TK}_{\% 25}(5.47 \mathrm{~g})$ sulama dozunda belirlenirken en yüksek verim ise $\mathrm{TK}_{\% 100}(12.00 \mathrm{~g})$ sulama dozunda meydana gelmiştir. Soya fasulyesinde verim sulama ve çeşit faktörlerine bağlı olarak önemli oranda değişirken kükürt gübre uygulamasının herhangi önemli bir etkisi gözlenmemiştir (Şekil 6). Tarımda su kullanım etkinliğinin arttırılmasının uygun teknik ile sulama miktarı ve zamanlamasının doğru bir şekilde yapılarak mümkün olduğu ifade edilmiştir (Tunalı ve ark. 2019). Choudhary ve ark. (2014) ise yaptıkları saks1 çalışmalarında kükürt ve çinko dozu uygulamalarının soya bitkisinde tek bitki verimi değerlerinin 9.8$15.3 \mathrm{~g}$ arasında değişerek uygulamaların önemli bir etkisinin bulunduğu ve bitki boyu, bitkide bakla sayıs1, 100 tane ağırlığı ve saksı veriminde artış meydana geldiğini belirtmişlerdir. Sulamalı koşullarda (\% 85-100 tarla kapasitesi) saksı koşullarında tek bitki verimi 13.5-19.6 g arasında değişmekle birlikte kısıtlı sulama koşullarında (\%30 tarla kapasitesi) ise 2.3-13.5 g değerleri arasında değiştiği belirtilerek sulamanın tek bitki verimi üzerinde önemli düzeyde etkili olduğu bildirilmiştir (He ve ark., 2017).

\section{Yaprak klorofil içeriği ve değişimi (SPAD)}

Soya fasulyesinde tane dolum dönemi boyunca yapılan klorofil içeriği (SPAD) okumaları bitkide azot asimilasyonunda su stresinin olumsuz etkilerini belirlemede en uygun yöntem ve zaman olduğu belirtilmiştir (Ahmed ve ark., 2010). Çalışmada bakla bağlama döneminde en düşük klorofil içeriği 2018 deneme y1lında Umut-2002 çeşidinde $\mathrm{TK}_{\% 50}$ sulama dozunda ve $0 \mathrm{~kg} / \mathrm{da}$ kükürt gübre dozunda ölçülmüştür. Buna karşın en yüksek klorofil içeriği 2018 deneme yılında Cinsoy çeşidinde $\mathrm{TK}_{\% 100}$ sulama dozunda ve $\mathrm{K}_{0}$ kükürt gübre dozunda saptanmıştır. Çeşitler arasında da bakla bağlama döneminde klorofil içeriği bakımından önemli farklar ortaya çıkmıştır (Çizelge 8).

$\mathrm{Bu}$ anlamda Cinsoy çeşidi denemedeki diğer iki çeşitten önemli oranda daha yüksek klorofil içeriğine sahip olmuştur. Tek bitki veriminde Cinsoy çeşidinin yüksek değer alması ve bakla bağlama dönemindeki yüksek klorofil içeriği önemli bir çeşit özelliği olarak dikkat çekmektedir. Sulama dozları arasında da önemli farklar meydana gelmiştir. Artan sulama dozları bakla bağlama döneminde klorofil içeriğinin artmasına neden olmuştur. Her bir sulama dozunda ortalama klorofil içeriğinde bir artış kaydedilmiştir, ancak bu artış $\mathrm{TK}_{\% 25}$ sulama dozu ile $\mathrm{TK}_{\% 75}$ sulama dozu arasında önemli olmamıştır ve bu üç sulama dozu aynı istatistiki grupta yer almıştır. TK ${ }_{\% 100}$ sulama dozunda denemedeki diğer sulama dozlarından önemli oranda bir artış elde edilmiştir. Kükürt gübre uygulamasının saksı koşullarında bakla bağlama döneminde pozitif bir etkisi belirlenememiştir ve her iki kükürt gübre dozu aynı istatistiki grupta bulunmuştur. Shafagh-Kolvanagh ve ark. (2008)'nın 
azotlu gübrelemeye bağlı olarak vejetatif gelişme dönemlerinde yaptıkları SPAD klorofil ölçümlerinde soya fasulyesinde V4 ve R3 dönemlerinde sirasiyla ortalama değerlerin 35.42 ile 27.88 arasında bulunduğu, bitki gelişim periyodu boyunca klorofil içeriğinin tüm azot uygulamalarında azaldığı ve bu dönemlerde yaptıkları SPAD okumalarının tane verimi ile yüksek düzeyde ilişkili olduğunu belirleyerek $\left(\mathrm{r}^{2}=0.86\right)$ erken dönemlerde verim tahminlemesinde yaprak klorofil varlığının önemli bir etmen olduğu sonucuna ulaşılmıştır.

Çizelge 8. Bakla bağlama dönemi yaprak klorofil içeriği ortalama değerleri (SPAD)

\begin{tabular}{|c|c|c|c|c|c|c|c|}
\hline \multirow{2}{*}{\multicolumn{2}{|c|}{ Yıl/Kükürt/Çeşit/Su }} & \multicolumn{3}{|c|}{$\mathrm{K}_{\mathbf{0} \mathrm{kg} / \mathrm{da}}$} & \multicolumn{3}{|c|}{$K_{5 \mathrm{~kg} / \mathrm{da}}$} \\
\hline & & Cinsoy & Arisoy & Umut-2002 & Cinsoy & Arisoy & Umut-2002 \\
\hline \multirow[t]{4}{*}{2017} & TK\%25 & $31.95 \mathrm{f}-\mathrm{o}$ & $28.47 \mathrm{p}-\mathrm{t}$ & $32.53 \mathrm{e}-\mathrm{k}$ & $26.23 \mathrm{st}$ & $29.62 \mathrm{k}-\mathrm{s}$ & $28.81 \mathrm{o}-\mathrm{t}$ \\
\hline & $\mathrm{TK}_{\% 50}$ & $32.44 \mathrm{e}-\mathrm{k}$ & 31.44 g-p & $32.35 \mathrm{f}-1$ & $34.00 \mathrm{c}-1$ & $28.79 \mathrm{o}-\mathrm{t}$ & $30.25 \mathrm{i}-\mathrm{r}$ \\
\hline & TK $_{\% 75}$ & $34.24 \mathrm{c}-\mathrm{h}$ & $27.27 \mathrm{rst}$ & $30.01 \mathrm{j}-\mathrm{r}$ & $31.29 \mathrm{~h}-\mathrm{q}$ & $28.93 n-s$ & $29.251-\mathrm{s}$ \\
\hline & $\mathbf{T K}_{\% 100}$ & $30.08 \mathrm{j}-\mathrm{r}$ & $29.53 \mathrm{k}-\mathrm{s}$ & $28.21 \mathrm{q}-\mathrm{t}$ & $33.03 \mathrm{~d}-\mathrm{j}$ & $29.11 \mathrm{~m}-\mathrm{s}$ & $30.37 \mathrm{i}-\mathrm{r}$ \\
\hline \multirow[t]{4}{*}{2018} & TK$_{\% 25}$ & $32.12 \mathrm{f}-1$ & $34.09 \mathrm{c}-1$ & $33.53 \mathrm{e}-\mathrm{k}$ & $34.48 \mathrm{c}-\mathrm{g}$ & $34.65 \mathrm{c}-\mathrm{f}$ & $32.48 \mathrm{e}-\mathrm{k}$ \\
\hline & $\mathbf{T K}_{\% 50}$ & $35.86 \mathrm{~cd}$ & $33.48 \mathrm{c}-1$ & $25.73 \mathrm{t}$ & $33.66 \mathrm{c}-1$ & $31.85 \mathrm{f}-\mathrm{p}$ & $33.10 \mathrm{~d}-\mathrm{j}$ \\
\hline & $\mathbf{T K}_{\% 75}$ & $36.13 \mathrm{~cd}$ & $36.11 \mathrm{~cd}$ & $34.60 \mathrm{c}-\mathrm{f}$ & $33.33 \mathrm{c}-\mathrm{i}$ & $34.18 \mathrm{c}-\mathrm{h}$ & $31.061-\mathrm{q}$ \\
\hline & TK $_{\% 100}$ & $40.13 \mathrm{a}$ & $36.28 \mathrm{bc}$ & 35.53 cde & $39.26 \mathrm{ab}$ & $35.86 \mathrm{~cd}$ & $35.96 \mathrm{~cd}$ \\
\hline
\end{tabular}

Lsd Y11: 0.633; Lsd Su: 0.896; Lsd YılxSu: 1.267; Lsd Çeşit: 0.776; Lsd Y1lxÇeşit: 1.097; Lsd SuxÇeşit: 1.552; Lsd Y1lxSuxÇeşit: 6.85; Lsd SuxKükürt: 1.267; Lsd Y1lxSuxKükürt: 1.792; Lsd SuxÇeşitxKükürt: 2.194; Lsd Y1lxSuxÇeşitxKükürt: 3.103

Bakla bağlama döneminde klorofil içeriği belirlendikten sonra tane dolum döneminde de klorofil içeriği (SPAD) ölçülmüştür. Farklı uygulamalar kapsamında tane dolum döneminde klorofil içeriği 12.33 ile 31.04 arasında değişerek önemli farkların meydana gelmesine neden olmuştur (Çizelge 9). Çeşitler arasında önemli farklar meydana gelmiştir. Soya çeşitlerinin bakla bağlama döneminden sonra ilerleyen gelişme dönemlerinden tane dolum döneminde yapılan ölçümlerde önceki ölçüme göre farklı sonuçlara ulaşılmıştır. Öncelikle ilerleyen gelişme dönemi içerisinde klorofil içeriğinde dikkate değer azalmaların olduğu gözlenmiştir. Bu azalma denemedeki tüm çeşitlerde görülmüştür.

Çizelge 9. Tane dolum dönemi yaprak klorofil içeriği ortalama değerleri (SPAD)

\begin{tabular}{|c|c|c|c|c|c|c|c|}
\hline \multirow{2}{*}{\multicolumn{2}{|c|}{ Yıl/Kükürt/Çeşit/Su }} & \multicolumn{3}{|c|}{$K_{0 \mathrm{~kg} / \mathrm{da}}$} & \multicolumn{3}{|c|}{$K_{5 \mathrm{~kg} / \mathrm{da}}$} \\
\hline & & Cinsoy & Arisoy & Umut-2002 & Cinsoy & Arisoy & Umut-2002 \\
\hline \multirow[t]{4}{*}{2017} & $\mathbf{T K}_{\% 25}$ & $23.45 \mathrm{j}-\mathrm{m}$ & $26.86 \mathrm{~d}-\mathrm{i}$ & $29.55 \mathrm{a}-\mathrm{d}$ & $22.83 \mathrm{k}-\mathrm{n}$ & $25.391-\mathrm{k}$ & 24.48 i-1 \\
\hline & $\mathbf{T K}_{\% 50}$ & $29.82 \mathrm{abc}$ & $28.70 \mathrm{~b}-\mathrm{g}$ & $31.04 \mathrm{ab}$ & $31.65 \mathrm{a}$ & $28.92 \mathrm{a}-\mathrm{f}$ & $30.06 \mathrm{abc}$ \\
\hline & $\mathrm{TK}_{\% 75}$ & $23.47 \mathrm{j}-\mathrm{m}$ & $26.53 \mathrm{e}-\mathrm{i}$ & $25.301-\mathrm{k}$ & $25.99 \mathrm{f}-\mathrm{j}$ & $27.86 \mathrm{c}-1$ & $22.121-0$ \\
\hline & $\mathrm{TK}_{\% 100}$ & $25.47 \mathrm{~h}-\mathrm{k}$ & 24.74 i-1 & $25.98 \mathrm{~g}-\mathrm{j}$ & 29.34 a-e & $26.00 \mathrm{f}-\mathrm{j}$ & $28.39 \mathrm{~b}-\mathrm{h}$ \\
\hline \multirow[t]{4}{*}{2018} & $\mathrm{TK}_{\% 25}$ & $15.53 \mathrm{u}-\mathrm{y}$ & $15.85 \mathrm{~s}-\mathrm{y}$ & $16.48 \mathrm{r}-\mathrm{w}$ & $17.31 \mathrm{r}-\mathrm{v}$ & $18.46 \mathrm{p}-\mathrm{t}$ & $18.55 \mathrm{p}-\mathrm{s}$ \\
\hline & $\mathbf{T K}_{\% 50}$ & $14.06 \mathrm{w}-\mathrm{z}$ & $15.01 \mathrm{v}-\mathrm{Z}$ & $19.23 \mathrm{o}-\mathrm{r}$ & $18.16 \mathrm{q}-\mathrm{u}$ & $21.02 \mathrm{~m}-\mathrm{q}$ & $22.55 \mathrm{k}-\mathrm{n}$ \\
\hline & $\mathrm{TK}_{\% 75}$ & $19.10 \mathrm{pqr}$ & $16.33 \mathrm{r}-\mathrm{w}$ & $15.73 \mathrm{~s}-\mathrm{y}$ & $17.23 \mathrm{r}-\mathrm{v}$ & $17.30 \mathrm{r}-\mathrm{v}$ & $21.13 \mathrm{~m}-\mathrm{p}$ \\
\hline & TK\%100 & $14.75 \mathrm{v}-\mathrm{z}$ & $12.85 \mathrm{yz}$ & $12.33 \mathrm{z}$ & $13.31 \mathrm{xyz}$ & $20.30 n-q$ & $14.78 \mathrm{v}-\mathrm{z}$ \\
\hline
\end{tabular}

Lsd Y1l: 0.599; Lsd Su: 0.848; Lsd Kükürt: 0.599; Lsd YılxSu: 1.199; Lsd Çeşit: 0.734; Lsd SuxÇeşit: 1.468; Lsd Y1lxSuxÇeşit: 2.076; Lsd Y1lxKükürt: 0.848; Lsd SuxKükürt: 1.199; Lsd Y1lxSuxKükürt: 1.695; Lsd Y1lxÇeşitxKükürt: 1.468; Lsd Y1lxSuxÇeşitxKükürt: 2.937

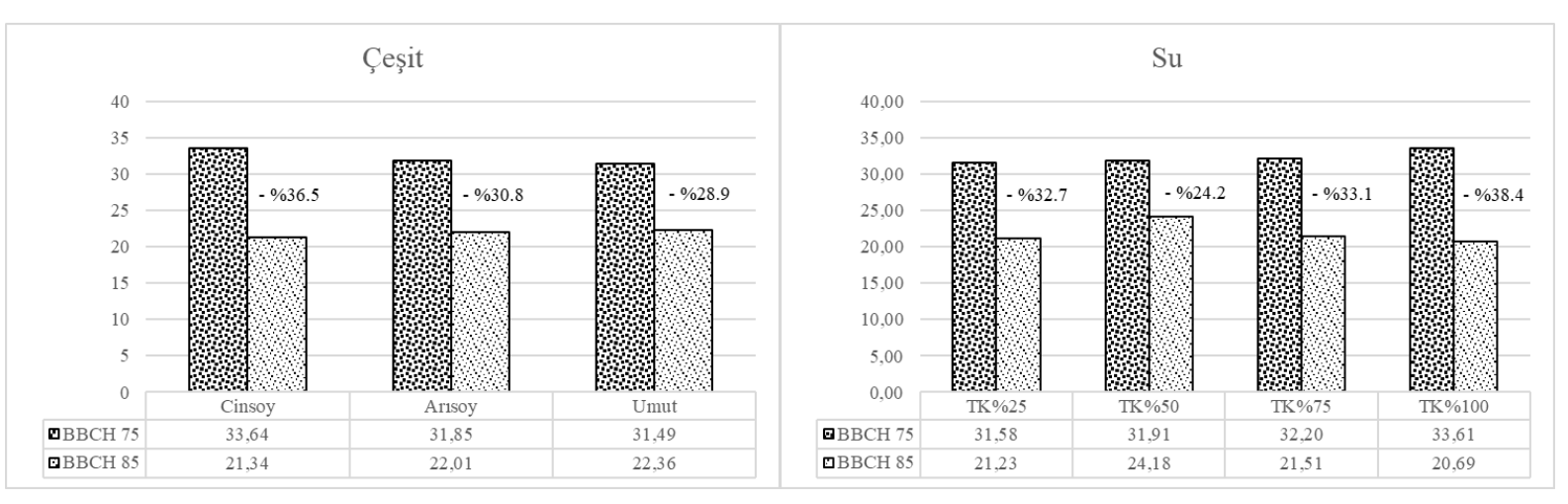




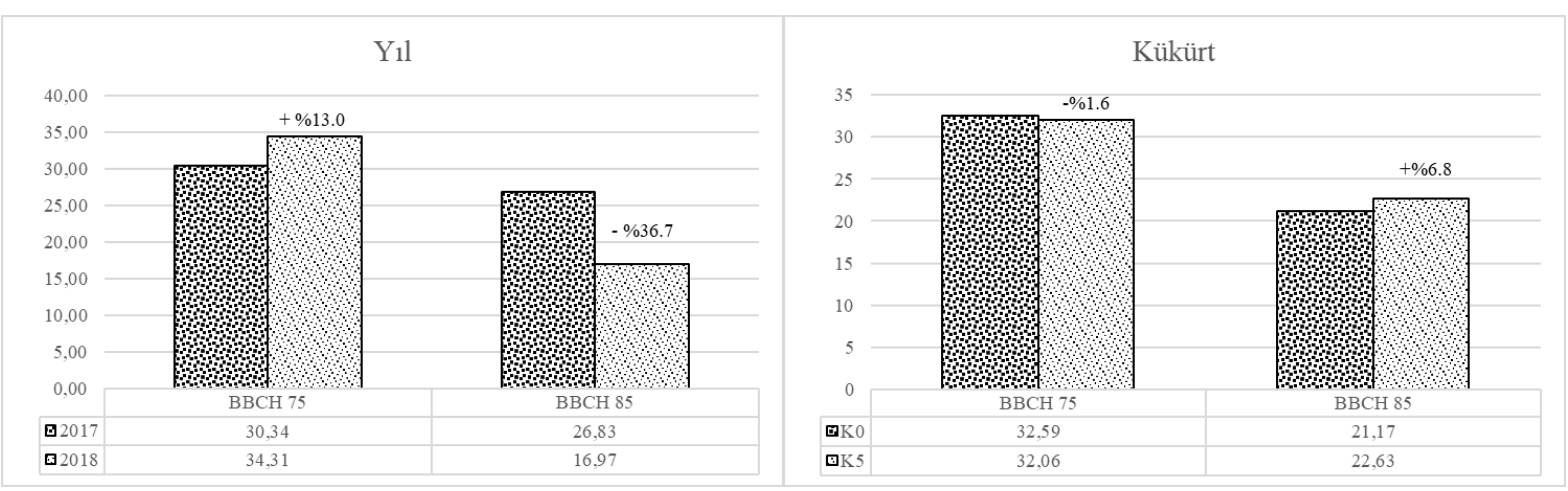

Şekil 7. Generatif dönemlerde (bakla bağlama ve tane dolum dönemi) yaprak klorofil içeriği ortalama değerleri ve değişim oranları

Çeşitler incelendiğinde bu dönemde en yüksek klorofil içeriği Umut-2002 çeşidinde ölçülmüştür. Ancak Elde edilen değerlerin öncelikle artan sıcaklıklar karşısında klorofil içeriğinin korunması açısından ve bu dönemde de fotosentez etkinliği hakkında önemli bilgiler vermektedir. $\mathrm{Bu}$ anlamda ilerleyen gelişme dönemlerinde daha yüksek klorofil içeriğine sahip çeşitlerin belirlenmesi önemlidir. Ayrıca ilerleyen gelişme döneminde çeşitlerin klorofil içeriğinin birbirine yaklaştığı da gözlenmiştir. Klorofil içeriği değişimi incelendiğinde çeşitler bazında en yüksek kaybın Cinsoy çeşidinde olduğu ve generatif gelişme döneminde yaşlanma belirtisi gösteren en önemli çeşit olduğu gözlemlenmiştir. Yüksek sıcaklık ve su stresi koşullarında tane dolum döneminde yapılan SPAD ölçümlerinde kontrol koşullarında 35.48, yüksek sıcaklık stresi koşullarında 36.84 ve su stresi koşullarında ise 22.38 değerleri elde edilerek su kıtlı̆̆ durumunda yaprak klorofil içeriğinin önemli oranda azaldığ 1 tespit edilerek tane dolum döneminde yapılan SPAD ölçümlerinin verim tahminlemesinde önemli düzeyde pozitif korelasyon gösterdiği belirtilmiştir (Ergo ve ark. 2018). Sulama dozu uygulamalarında ise en dikkat çekici nokta tane dolum döneminde $\mathrm{TK}_{\% 50}$ sulama dozunda en yüksek klorofil varlığının bulunmuş olmasıdır (Şekil 7.).

\section{Sonuç ve Öneriler}

Yapılan çalışma ile kontrollü koşullarda sulama miktarı ve kükürtlü gübre dozları ile soya fasulyesi bitkisinde verim ve fizyolojik parametreler incelenmiştir. Yapılan çalışma ile soya fasulyesi üretiminde sulama faktörünün oldukça büyük önem arz ettiği ve kullanılan çeşitlerin genetik performansına göre verimlilik özellikleri büyük ölçüde etkilendiği anlaşılmıştır. Artan sulama dozu ve topraktaki su miktarı ile bitkilerde verim ve fotosentez etkinliğinin genel olarak arttığı anlaşılmaktadır. Özellikle bitkide bakla sayısı ve tek bitki verimi açısından $\mathrm{TK}_{\% 100}$ düzeyinde sulama ile yüksek verim alındığı soya fasulyesi yetiştiriciliğinde toprak neminin yüksek tutulması ve sıcak iklim şartlarında tarla kapasitesi düzeyinde sulama yapılması verimlilik açısından önem arz etmektedir. Generatif dönemlerde yapılan klorofil ölçümlerinde bitkinin olgunlaşması ile yaprak klorofil içeriğinin azaldığı ve çeşit ve sulama faktörlerinden önemli oranda etkilendiği anlaşılmıştır. Umut-2002 çeşidi bu dönemlerde en az düzeyde klorofil (SPAD) kaybının yaşandığı çeşit olması nedeniyle dikkat çekerken, Cinsoy çeşidinin yapraklarında erken olum ve yaşlanma etkisi gözlemlenmiştir. Alkali toprak koşullarında yapılan çalışmada kükürtlü gübre dozlarının etkisi belirgin bir şekilde gözlemlenmemiştir. Arısoy çeşidi hem tek bitki verimi hem de bitkide bakla sayısı bakımından \%100 tarla kapasitesi koşullarında en yüksek değerleri alarak soya fasulyesi üretiminde yeterli düzeyde yapılacak sulamada bölgemiz topraklarında ön plana çıkabilme potansiyeli vardır. Sera koşullarında yapılan çalışma ile birlikte elde edilen bilgilerin ışığında çeşitlerin tarla koşullarında da sulama performanslarının değerlendirilmesi gerekmektedir.

Teşekkür

Yapılan çalışma TÜBİTAK EIG Concert Japan İkili İş birliği kapsamında desteklenen 1170378 no'lu projenin bir bölümünü kapsamaktadır. Yaptıkları desteklerden ve sağladıkları proje imkanından dolayı TÜBİTAK'a teşekkür ederiz. 


\section{Kaynaklar}

Açıkgöz, N., İlker, E., Gökçöl, A., 2004. Assessment of biological research on the computer. ISBN: 973-483607-8, Ege University Seed Technology Center, No: 2, Bornova-İzmir.

Ahmed, S.U., Senge, M., Ito, K., Adomako, T., 2010. Effects of water stress on soil plant analytical development (SPAD) chlorophyll meter reading and its relationship to nitrogen status and grain yield of soybean under different soil types. Journal of Rainwater Catchment Systems, 15 (2): 33-38.

Arıŏlu, H., Güllüoğlu, L., 2019. Soya'da tohumluk üretimi ve sertifikasyonu, Tohum, Tohumculuk ve Teknolojileri, BİSAB, Cilt 2, 811-837.

Boydak, E., Kayantaş, B., Acar, F., Fırat, R., 2018. Bazı soya fasulyesi (Glycine max L.) çeşitlerinin yüksek rakımlarda verim ve verim unsurlarının belirlenmesi, Harran Tarım ve Gıda Bilimleri Dergisi. 22 (4), 544-550.

Canavar, Ö., Götz, K.P., Ellmer F., Chmielewski, F.M., Kaynak, M.A., 2014. Determination of the relationship between water use efficiency, carbon isotope discrimination and proline in sunflower genotypes under drought stress", Australian Journal of Crop Science, 8 (2), 232-242.

Cazzato E., Tufarelli V., Ceci E., Stellacci A.M., Laudadio, V., 2012. Influence of sulphur application on protein quality, fatty acid composition and nitrogen fixation of white lupin (Lupinus albus L.). European Food Research and Technology, Volume 235, Issue 5, pp 963-969.

Choudhary, P., Jhajharia, A., Kumar, R., 2014. Influence of sulphur and zinc fertilization on yield, yield components and quality traits of soybean (Glycine max L.). The Bioscan, 9 (1): 137-142.

Dede, Ö., Acar, İ., 2019. Yapraktan ve topraktan uygulanan çinkonun soya fasulyesinin (Glycine max L.) verim ve verim öğeleri üzerine etkileri, Ordu Üniv. Fen Bilimleri Enst. Yüksek Lisans Tezi, 47 sayfa.

Divito G.A., Sainz Rozas H.R., Echeverra H.E., Wyngaard, N., 2013. Long-term sulfur fertilization: Effects on crops and residual effects in a no-till system of Argentinean pampas, Communications in Soil Science and Plant Analysis, 44:12, 1800-1813.

Doğan, Y., Koyutürk, Ö., Aktaş, H., 2015. Mardin-Kızıltepe ekolojik koşullarında ekim zamanı uygulamalarının bazı soya fasulyesi çeşitlerinde verim ve verim öğeleri üzerine etkisi. YYÜ Tarla Bitkileri Dergisi. 25(3), 293-303.

Ercoli, L., Lulli, L., Arduini, I., Mariotti, M., Masoni, A., 2012. Management of sulphur fertiliser to improve durum wheat production and minimise S leaching. Europ. J. Agronomy 38: 74- 82.

Ergo, V.V., Lascano, R., Vega, C.R.C., Parola, R., Carrera, C.S., 2018. Heat and water stressed field-grown soybean: A multivariate study on the relationship between physiological-biochemical traits and yield. Environmental and Experimental Botany, 148: 1-11.

FAOSTAT, 2019. Food and Agriculture Organization of the United Nations statistics. Erişim: http://www.fao.org/faostat/en/\#data. Erişim Tarihi: 25.01.2020.

He, J., Du, Y.L., Wang, T., Turner, N.C., Yang, R.P., Jin, Y., Xi, Y., Zhang, C., Cui, T., Fang, X.W., Li, F.M., 2017. Conserved water use improves the yield performance of soybean (Glycine max (L.) Merr.) under drought. Agricultural Water Management, 179: 236-245.

Hu, M., Wiatrale, P., 2012. Effect of planting date on soybean growth, yield and grain quality, Agron. J. 104, 785-790.

İlker, E., 2017. Performances of soybean [Glycine $\max$ (L.) Merr.] advanced lines grown in second cropping under Mediterranean climatical conditions of Western Turkey. Turkish Journal of Field Crops. 22 (1): 104-107.

Jaga, P.K., 2013. Effect of sulphur, zinc and bio-fertilizer on soybean. An Asian Journal of Soil Science, 8(2): 505-509.

Jamal A., Fazli I. S., Ahmad S., Abdin M.Z., 2006. Interactive effect of nitrogen and sulphur on yield and quality of groundnut (Arachis hypogea L.). Korean J Crop Sci., 51(6): 519-522.

Kaya, M., Karaman, R., Şener, A., Odabaşığlu,, C., 2017. Soya fasulyesinde Fe-Humat, Fe-Fulvat ve Molibden uygulamalarının nodülasyon ve bazı fide özelliklerine etkileri, International Multidisciplinary Congress of Eurasia.

Koca, Y.O., Canavar, Ö., Yorulmaz, A., Erekul, O., 2015. Influence of nitrogen level and water scarcity during seed filling period on seed yield and fatty acid compositions of corn. Philippine Journal of Crop Science 40(3): 98-105.

Kocaturk, M., Cubukcu, P., Goksoy, A.T., Sincık, M., Ilker, E., Kadıroglu, A., Vurarak, Y., Sahın, Y., Karakus, M., Yıldırım, U.A., 2019. GGE biplot analysis of genotype $\mathrm{x}$ environment interaction in soybean grown as a second crop. Turkish Journal of Field Crops, 24 (2): 145-154.

Krusell, L., Krause, K., Ott, T., Desbrosses, G., Krämer, U., Sato, S., Nakamura, Y., Tabata, S., James, E.K., Sandal, N., Stougaard, J., Kawaguchi, M., Miyamoto, A., Suganuma, N., Udvardi, M.K., 2005. The sulfate transporter SST1 is crucial for symbiotic nitrogen fixation in lotus japonicus root nodules. The Plant Cell 17, 1625-1636.. doi:10.1105/tpc.104.030106. 
Ma, H., Sonoko, M., Wirth, S., 2019. Effect of biochar and irrigation on the interrelationships among soybean growth, root nodulation, plant p uptake and soil nutrients in a sandy field. Sustainability, 11, 6542.

Mbow, C., Rosenzweig, C., Barioni, L.G., Benton, T.G., Herrero, M., Krishnapillai, M. Liwenga, E., Pradhan, P. Rivera-Ferre, M.G., Sapkota, T., Tubiello, F.N., Xu, Y., 2019. Food Security. In: Climate Change and Land: an IPCC special report on climate change, desertification, land degradation, sustainable land management, food security, and greenhouse gas fluxes in terrestrial ecosystems [P.R. Shukla et al. (eds.)]. In press.

Muandemela, O.D., Doto, A., 2010. Evulation of soybean lines for drought tolerance and the influence of water avalability on cookability, Turialba. 38, 194-197.

Onat, B., Bakal, H., Güllüoğlu, L., Arığlu, H., 2017. The effects oh high temperature at the growing period on yield and components of soybean (Glycine max L.) varieties, Turkish Journal of Field Crops. 22 (2), 178-186.

Shafagh-Kolvanagh, J., Zehtab-Salmasi, S., Javanshir, A., Moghaddam, M., Nasab, A.D.M., 2008. Effects of nitrogen and duration of weed interference on grain yield and SPAD (chlorophyll) value of soybean (Glycine max. (L.) Merrill.). Journal of Food, Agriculture and Environment, 6 (3\&4): 368-373.

Sincik, M., Candoğan, B.N., Demirtaş, C., Büyükcangaz, H., Yazgan, S., Göksoy, A.T., 2008. Deficit irrigation of soybean (Glycine $\max$ (L.) Merr.) in a sub-humid climate, Journal of Agronomy and Crop Science, 194: 2005-205.

Sinclair, T.R., Purcell, L.C., King, C.A. Sneller, H., 2007. Drought tolerance and yield increase of soybean resulting from improved symbiotic $\mathrm{N}_{2}$ fixation, Field Crop Research. 101, 68-71.

Streeter, J.G., 2003. Effects of drought on nitrogen fixation in soybean root nodules, Plant, Cell and Environment, 26,1199-1204.

Tuğay, E., Atikyılmaz, N., 2009. Ege Bölgesinde ana ürün koşullarında bazı soya genotiplerinin verim, verim öğeleri ve nitelikleri üzerinde bir araştırma. Anadolu, J. of AARI. 19 (1): 34-46.

Tunalı, S.P., Gürbüz, T., Akçay, S., Dağdelen, N., 2019. Aydın koşullarında pamuk çeşitlerinde su stresinin verim ve verim bileşenleri ile lif kalite özellikleri üzerine etkileri. ÇOMÜ Ziraat Fakültesi Dergisi, 7 (1): 161-168.

TÜİK, 2019. Türkiye İstatistik Kurumu, Bitkisel Üretim İstatistikleri. Erişim: www. tuik.gov.tr. Erişim Tarihi: 25.01.2020.

Ünal, İ., 2007. Melezleme yöntemiyle elde edilen soya [Glycine max (L.) Merr.] hatlarının bazı tarımsal özelliklerinin belirlenmesi", Selçuk Üniversitesi, Fen Bilimleri Enstitüsü, Yüksek Lisans Tezi, Konya, $54 \mathrm{~s}$.

Yıldırım, A., İlker, E., 2018. Ege Bölgesi’nde ikinci ürün koşullarında bazı soya çeşit ve hatlarının verim ve agronomik özellikleri ile kalite özelliklerinin belirlenmesi. Adnan Menderes Üniversitesi Ziraat Fakültesi Dergisi. 15 (2): 1-8.

Yıldırım, A., Yıldı, H., İlker, E., Ekren, S., 2020. Determination of yield and agronomic characteristics of some soybean genotypes suitable for double crop agriculture in Mediterranean climate conditions. In: Brka M., Omanović-Mikličanin E., Karić L., Falan V., Toroman A. (eds) 30th Scientific-Experts Conference of Agriculture and Food Industry. AgriConf 2019. IFMBE Proceedings, vol 78. Springer, Cham. 